\title{
FROM THE EDITOR...
}

The Mahaweli river which is ranked as the longest river in Sri Lanka, has a drainage basin about one fifth of the total area of the country. Receiving water from two monsoons, it is the most feasible river to be harnessed for the development and prosperity of the country. After the independence from the British empire in 1948, the government of Ceylon soon embraced its development initiatives by harnessing the Mahaweli river with the modern knowledge of science and engineering.

The Mahaweli Development Program (MDP) is known as the largest multipurpose

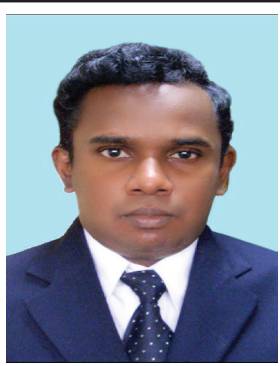
national development program in the history of Sri Lanka and is also considered as the keystone of the government's development program. In 1961, then government of Ceylon requested assistance from the Special Fund of the United Nations to survey the Mahaweli river basin and the dry zone areas. The funding was approved and the project operation started in 1964. The survey was carried out in two stages: in the first stage between 1965 and 1967 a field investigation of the entire project area with the aim of developing an outline for a Master Plan for the full development of the water resources for irrigation and hydropower was performed; in the second stage between 1967 and 1968 all the three phases of development for the entire scheme were identified, additional investigations were carried out in the areas selected for the three projects to be included in the first phase of development and detailed designs were prepared.

Execution of the project one of the first phase, which included Polgolla headworks, commenced in 1970. The first phase of the program consisted of diversion headworks at Polgolla and Bowatenna, $40 \mathrm{MW}$ hydropower plant at Ukuwela and an improved water supply to about 52,700 ha of existing irrigated land. Phase one was completed in 1976 and the step-wise implementation of the Mahaweli Development Programme would have lasted about 30 years from 1975. However, the newly appointed government in 1977 decided to accelerate the program and complete it within its term of office of 6 years. Accordingly, the Accelerated Mahaweli Programme (AMP) was implemented with a revision of the Master Plan in 1977. AMP consisted of 12 projects and mainly confined to four head works in the initial works of the program, including the construction of Kotmale (200MW), Victoria (210MW), MaduruOya (25MW), Randenigala (135MW), Rantambe (52MW) dams, and the Ulhitiya and Ratkindatwin reservoirs. In line with initial objectives, Upper Kotmale dam (150 MW) and Moragahakanda (25MW) were constructed in 2012 and 2018, respectively.

Among dams constructed over Mahaweli river, the Moragolla dam is one of the last reservoirs in Mahaweli river and it is a planned hydroelectric dam in Moragolla, Ulapane. It was first identified in the "Report on a Survey of Resources of the Mahaweli Ganga basin, Ceylon, Hunting Survey Corporation, 1962 " prepared in cooperation with the Survey General of Ceylon. The concrete gravity dam is to be $35 \mathrm{~m}$ high and is planned to create the $1,980,000 \mathrm{~m}^{3}$ Moragolla reservoir with a maximum supply level at $548 \mathrm{~m}$ MSL. Upon completion, the Moragolla Power Station would have a gross installed capacity of 30.2MW from two Francis turbines, capable of generating approximately 85 GWh annually. Preliminary assessments and feasibility studies of the hydroelectric dam and power station began in 2012, with an estimated commissioning date in 2021. The dam is planned to impound the Mahaweli river at Weliganga and have five spillways, with the powerhouse located approximately $500 \mathrm{~m}$ from the tailrace discharge of the Kotmale power station.

Sixty years after the initiation of MDP, the country has now truly moved forward towards its initial goals of development and prosperity. As a nation of high human qualities, generous financial and technical assistance provided by a number of Eastern and Western countries are also to be remembered at the $60^{\text {th }}$ anniversary of the initiation of the MDP.

Eng. (Dr.) P.A.K. Karunananda

BSc. (Eng.) (Hons.) (Peradeniya), MPhil. (Peradeniya), MEng. (Ehime), DEng. (Ehime), C.Eng, MIE(SL) Editor, 'ENGINEER', Journal of The Institution of Engineers 